\title{
Economic resilience in Great Britain: the crisis impact and its determining factors for local authority districts
}

\author{
$\operatorname{Anastasios~Kitsos~}^{1,2}$ (D) Paul Bishop ${ }^{2}$
}

Received: 24 March 2016 / Accepted: 14 October 2016 / Published online: 22 November 2016

(C) The Author(s) 2016. This article is published with open access at Springerlink.com

\begin{abstract}
The 2008 recession has had a prolonged and varying effect both across and within countries. This paper studies the crisis impact on Great Britain's Local Authority Districts (LADs) using the concept of economic resilience. This country is an interesting case study as the impact varied significantly among LADs. The focus is on employment, and a new method is proposed for comparing pre- and post-recession conditions in order to assess the recession impact. The influence of a number of determining factors is examined, and the study finds a significant effect for initial economic conditions, human capital, age structure, urbanisation and geography. Policy makers need to take into account subnational differences in these factors in order to design and implement better targeted policies.
\end{abstract}

\section{JEL Classification R11}

\section{Introduction}

The 2008 economic crisis has had a global impact which is still being felt in a number of countries. In the UK, in addition to a decrease in output, the crisis led to a drop of $2.3 \%$ in the rate of employment and an increase of $2.8 \%$ in the rate of unemployment between 2007 and 2011. At the subnational level, there have been significant variations in the performance of different areas; for example, during the same period, Tamworth in Staffordshire lost $11.8 \%$ of its employment, whilst Hackney in London gained $5.6 \%$. These wide variations lend credence to the arguments of a number of researchers

\footnotetext{
$\triangle$ Anastasios Kitsos

a.kitsos@bham.ac.uk

1 City-REDI, Birmingham Business School, University of Birmingham, Birmingham, UK

2 Economics Department, Plymouth Business School, Plymouth University, Plymouth, UK
} 
that economic downturns impact on localities in significantly different ways and with varying levels of severity (Capello et al. 2016; Fingleton et al. 2012).

The magnitude of the downturn and its differential impact across various areas have sparked research on identifying the underlying factors behind these differences as well as whether it is possible to influence these factors. The concept of resilience, broadly defined as the ability of a system to withstand or overcome a shock-economic or otherwise-provides one useful framework to study these questions. Within the context of the recent crisis, it is useful to identify two stages in the process of examining resilience - the initial impact/downturn or recession phase and the rebound/adaptation or recovery phase (Fingleton et al. 2012; Lee 2014; Martin and Sunley 2014).

Recent empirical research on resilience focuses on examining quantifiable economic indicators such as GDP, employment and unemployment (Cellini et al. 2014; Fratesi and Rodríguez-Pose 2016; Lee 2014; Martin and Sunley 2014). A number of studies examine "peak" to "trough" differences at the national, regional or city level (Lee 2014) during the period 2008-2010. However, with 240 out of 380 GB Local Authority Districts (LADs) reaching their minimum employment rate after 2010, most of these studies fail to consider the full extent of the crisis. In addition, the use of the difference between two single points in time is subject to potentially significant errors arising from survey data based on small samples at the subnational level. As a consequence, single observations may suffer from high levels of volatility and weak reliability as evidenced by large confidence intervals for data such as unemployment at the subnational level in Great Britain.

This study focuses on the impact of the 2008 recession on local labour markets and the factors behind it using an econometric analysis of data at the GB LAD level. A new method of calculating the crisis impact is proposed which involves averaging the annual data on pre- and post-2008 employment performance and examining the change of these averages in order to ameliorate the issues associated with singleyear observations. The paper begins by reviewing recent developments in the study of economic resilience and the factors behind resilience performance. Section 3 discusses the data and methodology, whilst Sect. 4 presents the results. Finally, Sect. 5 concludes and discusses further steps for research. To the authors' knowledge, this is the first study based on the methodology and variables discussed as well as its focus on the GB's 380 LADs.

\section{Economic resilience}

\subsection{Concept and measurement}

Definitions of economic resilience can be broadly categorised into equilibrium and evolutionary approaches even though recent developments reconcile the two by suggesting that the former could be part of the latter (Di Caro 2015a). Equilibrium approaches consider resilience either as a return to a pre-existing equilibrium (engineering resilience) or as a movement towards a new state (ecological resilience). Engineering resilience is typically measured in terms of speed of return to equilibrium (Fingleton et al. 2012; Hill et al. 2010; Holling 1996; Martin and Sunley 2014), 
whilst ecological resilience is measured by the force required before the structural characteristics of a system change permanently (Holling 1996; Martin 2012). One specific example of this approach is offered by Hill et al. (2010) in which resilience is treated as the ability of a place to return to a previously defined growth path within a certain timeframe. In contrast, evolutionary perspectives treat resilience as a continuum of adaptation to constantly changing conditions (Bristow and Healy 2013; Martin and Sunley 2014; Walker et al. 2004). As a result, resilience includes the possibility for adaptive capacity building and creation of a new sustainable path with improved qualitative characteristics (Martin and Sunley 2014).

A wide range of methods have been used in the study of economic resilience. For example, Treado and Giarratani (2008) and Simmie and Martin (2010) use qualitative research methods, Martin (2012) and Di Caro (2015a) investigate the topic quantitatively, whilst Hill et al. (2010) use mixed methods.

Quantitative measures of resilience have typically focused on single proxies, mainly examining labour market aspects (Di Caro 2015b; Fingleton et al. 2012). Lee (2014), for example, studies the crisis impact on British cities using changes in unemployment rates and claimant counts, whilst Fingleton et al. (2012) examine the employment performance of GB regions. The rationale for focusing on labour markets is related to both practical and theoretical considerations. Labour market data tend to be more readily available and reliable at lower geographical levels than output measures such as GVA for which the method of calculation at the subnational level has been criticised (Gripaios and Bishop 2006). In addition, labour market adjustments are one of the main options available for firms to reduce costs during a recession, and hence, the impact of a crisis may manifest itself particularly strongly in such markets (Fingleton et al. 2012). As a result, investigating employment conditions becomes instrumental in understanding the impact of the recession on local areas, and this is the approach taken in this study. However, it should be noted that in countries with greater institutional rigidity, GDP measures may better reflect economic fluctuations (Cellini and Torrisi 2014).

Within labour markets, a number of potential indicators might be used including those covering employment, unemployment and claimant count data, all of which have their own merits and disadvantages. As Lee (2014) notes, for example, claimant count data may exclude unemployed foreign migrant workers who are ineligible to claim benefits and those who retire early due to a lack of employment prospects. These data may also be biased towards those on lower incomes who may claim benefits more rapidly than those who had higher incomes and use savings as a buffer against unemployment. Similarly, unemployment data exclude those who retire early in response to a shock and are based on survey data with large sampling errors at a local level. Indeed, data and confidence intervals for many LADs are not published due to very small sample sizes.

Given these considerations, in common with several recent studies, this paper focuses on employment (see e.g. Fingleton et al. 2012; Simmie and Martin 2010; Hill et al. 2010). This measure consists of people aged 16 and over who did paid work (as an employee or self-employed), those who had a job that they were temporarily away from, those on government-supported training and employment programmes and those doing unpaid family work. This measure has a relatively large sample ensuring that data are available for most LADs. The data also cover all those employed and avoid 
the exclusion of migrant workers. As the sample areas differ considerably in size, the analysis focuses on employment rates rather than absolute numbers. Whilst employment rates are clearly an important indicator of economic activity, changes in rates may reflect a variety of factors including the impact of workers retiring earlier than anticipated due to the shock, migration flows in response to differential employment opportunities and changes in the number of individuals accessing training or educational programmes. Hence, they incorporate the net impact of demand side shocks and supply side responses in the local labour market.

\subsection{Determinants of resilience}

In examining the determining factors of the crisis impact, this paper draws on existing research on resilience and theoretical perspectives on growth and employment. A number of variables, such as indicators of good governance, social capital and public investment could not be included due to lack of data at the LAD level. Consequently, the analysis concentrates on factors for which quantitative data are available; these include measures of pre-crisis economic conditions, industrial structure, industrial diversification, entrepreneurship, human capital, demographics, population density and geography. The rationale for the inclusion of these factors is now discussed in turn.

At the onset of the financial crisis, GB regions were characterised by differing precrisis economic conditions, past investments and resource endowments. The theory of path dependency suggests that such factors may potentially constrain or enhance the ability of a region to adapt to a crisis (Lee 2014; Martin and Sunley 2014) and, hence, it is essential to explore the impact of these initial conditions. In terms of precrisis labour market conditions, the empirical literature has been inconclusive with Lee (2014), suggesting that the largest increases in unemployment were in places with already high unemployment rates but the opposite is true when claimant counts are examined. These mixed results suggest that there is a need for further research on the impact of initial labour market conditions.

Related to the effect of pre-existing economic conditions is the sectoral composition of employment. Different sectors exhibit varying demand, supply, competition and location characteristics which could translate into differences in the local impact of the recession. Due to the origin of the 2008 financial crisis, it might be thought that the sectoral impact was greater on services such as finance and banking, real estate and construction (Lee 2014) and lower in the public sector, which acted as a buffer during the initial recession period (2008-2010) (Clayton 2011). Hence, it is important to test whether the sectoral composition of pre-crisis employment had an effect on its impact.

The sectoral composition of employment could also be an indication of industrial diversity. Although a degree of specialisation is often considered beneficial to growth through increased competitiveness and externalities, it may leave local economies exposed to business cycles that impact on these specialised sectors (Di Caro 2015b). Following the same principles as portfolio diversification, it is possible that a drop in demand will have a greater impact in an area where a large number of firms depend on 
customers with similar characteristics. Consequently, areas with greater diversification might exhibit a smaller crisis impact (Di Caro 2015b; Lee 2014).

Entrepreneurship could also play a role in mitigating the effects of the downturn (Bishop and Shilcof 2016). A number of studies highlight the importance of entrepreneurship to economic growth through innovation and job creation (Audretsch et al. 2015; Williams et al. 2013). However, firm formation exhibits significant geographical and time persistent differences (Acs and Mueller 2008; Bishop 2012). In the UK, Fotopoulos (2014) provides evidence on the time persistent spatial stickiness (slow propensity to change) of entrepreneurship for the period 1994-2007. The flexibility and innovation aspects of entrepreneurial activity are key to identifying and exploiting opportunities during a crisis (Soininen et al. 2012), whilst firm formation can replace the existing stock of firms with more dynamic ones. Higher rates of firm births may imply more opportunities for employment growth and less impact from the economic downturn.

Human capital could have an important effect on resilience through at least two channels. First, skilled employees are a highly valued asset due to embedded knowledge and experience (Lee 2014). In the face of reduced demand, it is possible that firms may opt for hoarding this type of labour (Clayton 2011). As a result, places with more workers with high level qualifications may exhibit a lower crisis impact. The second channel is via human and firm-specific capital created through on-the-job training (Becker 1962; Hashimoto 1981). A number of researchers find that increasing rates of training are associated with reduced likelihoods of lay-offs and staff turnover (Becker 1962; Hashimoto 1981; Molina and Ortega 2003). However, evidence from North America suggests that firms with higher rates of training tend to be less technologically advanced, more unionised and with low rates of R\&D (Molina and Ortega 2003). These opposing characteristics suggest that the net impact of such training can only be identified by empirical analysis.

Human capital stocks are subject to accumulation as well as obsolescence and depreciation during an individual's lifetime (Brunow and Hirte 2009a, b; Skirbekk 2004). Age has also been negatively associated with labour mobility and flexibility which could translate to slower structural adjustment in local economies (Poot 2008; Robertson and Tracy 1998). Even though younger people may be more flexible and adaptable than older workers, productivity may rise with experience for a number of working years. As a result, demographics could significantly affect the recession impact, and it is interesting to examine whether it is the flexibility or experience effects that dominate.

The existing literature suggests that cities have a special role to play with regard to resilience (Capello et al. 2015). Larger cities may be more diverse and less susceptible to changes in demand. In addition, firms in large cities tend to focus more on human capital and innovation intensive activities rather than production and benefit from agglomeration economies (Capello et al. 2015; Lee 2014). Hence, urban areas may benefit from increased proportions of human capital and the potential for skilled labour hoarding. Empirical studies provide support for the argument that urban or denser areas performed better during the 2008 economic crisis (Capello et al. 2015). Even though the existing explanatory variables cover some characteristics of cities such as 
human capital, it is important to include a measure of urbanity to account for other agglomeration factors.

Due to spatial stickiness and location specific factors, the crisis may have had a geographically diverse impact. Martin (2012), for example, finds significant regional variations during different UK crises with broad differences between the peripheral, northern UK and the West Midlands on the one hand and the South and East on the other hand. For the 2008 crisis, the initial expectation was that there would be a severe impact on places with high shares of financial services activities. However, a stream of research suggests that the crisis rapidly spreads to sectors linked to finance (Lee 2014) and, consequently, the 2008 recession resembles the early 1980s in terms of having a more negative effect on the labour markets in the North (Lee 2014; Martin 2012). These factors are examined by the incorporation of various regional dummies.

\section{Data and variables}

\subsection{Dependent variables}

This paper argues that, irrespective of one's view on the conceptualisation of resilience, quantitative measurement is an essential component of understanding the impact of the crisis. Consequently, in gauging the crisis impact on labour markets, the paper compares the conditions before and after the 2008 downturn using quantitative employment indicators.

The period of study covers the years from 2004 to 2014. The start year is chosen to ensure consistency since in 2004 the Annual Population Survey (APS), from which the employment data are extracted, replaced the Local Area Population Survey which used different periods for its estimation of employment rates. The APS combines quarterly data from the Labour Force Survey and rolling year data from the Local Labour Force Survey to provide the largest coverage in the UK.

LADs have been chosen as the geographical level for this study because they are the lowest administrative level in which policies can be pursued both for the mitigation of the crisis' effects and for preparing for the recovery stage. The average population of a LAD for 2007 was approximately 150,000 with the Isle of Scilly being the smallest, counting for only 2300 and Birmingham being the largest with 1,029,000 citizens. In addition, compared to travel-to-work areas (TTWAs), the LADs provide a significantly richer dataset covering the period since 2004 with, for example, employment rates for TTWAs from the APS being available only from 2013 onwards.

Given that the period 2004-2007 was one of relative labour market stability at the national level, with age 16+ employment rates of $59.7 \%$ in 2004 and $59.9 \%$ in 2007 , it is possible to construct an average rate of employment during this period to act as an initial point against which subsequent performance can be measured. In this way, it is possible to overcome problems associated with the volatility of these rates at the LAD level. Table 1 shows that averaging over the four-year period is highly correlated with two- and three-year averages as well as the 2007 employment rate. However, the four-year average may better reflect the concept of an "equilibrium" point prior to the recession and help to ameliorate any volatility effects for individual areas at the subnational level. 
Table 1 Correlation matrix of average employment rates for 2004-2007, 2005-2007, 2006-2007 and employment rates 2007

\begin{tabular}{lllll}
\hline Variable & AVERAGE06-07 & AVERAGE05-07 & AVERAGE04-07 & EMPLOYMENT07 \\
\hline AVERAGE06-07 & 1 & & & \\
AVERAGE05-07 & 0.9862 & 1 & & \\
AVERAGE04-07 & 0.9703 & 0.9929 & 1 & 1 \\
EMPLOYMENT07 & 0.9578 & 0.9367 & 0.9198 & 1 \\
\hline
\end{tabular}

Taking the difference between this initial employment average and the respective minimum for the period 2008-2014 would create a variable reflecting the recession's impact in LADs. However, to ensure consistency with the averaging approach used for the pre-recessionary period, the minimum employment point is calculated by averaging the lowest four rates during 2008-2014. This also accounts for any potential lag of the crisis impact on LADs. The difference between the initial and minimum averages provides a direct measure of the employment impact and the ability to measure the effect of the independent variables on the dependent in absolute terms.

This method differs from some approaches such as that of Martin (2012) in that it does not consider the change at the national level as mediating the results. The reason for this is that this study does not attempt a categorisation of LADs into resilient or non-resilient and nor does it compare areas across countries in which case controlling for national effects would be needed. Rather, the study is focused on comparing LADs within a country and, more importantly, in identifying the determining factors behind the magnitude of the crisis impact on these LADs. Dividing the crisis impact on LADs by the impact at the national level would simply scale the original results with no effect on the substance of the analysis.

A drop of a certain percentage in employment can have varying importance for different places depending on their initial conditions. Hence, the differences between the initial and minimum points in such studies could be measured in terms of both level (variable IMPACT) and percentage change. In this study, the level and percentage change exhibit a high correlation (0.99) which leads to similar results in the analysis and as such only the results for the level difference (IMPACT) are reported. Despite the high correlation, there are methodological grounds for examining both measures as these may potentially lead to more varied results when examining other labour market statistics. The formula for the dependent variable is IMPACT $=X_{j}-X_{i}(1)$ where $X_{j}$ is the average employment for 2004-2007 in region $j, X_{i}$ is the average of the four minimum employment rates during 2008-2014 and its descriptive statistics are shown in Table 2.

Table 2 Descriptive statistics of crisis impact variable

\begin{tabular}{llllll}
\hline & Obs & Mean & SD & Min & Max \\
\hline IMPACT & 378 & 3.12 & 2.43 & -7.33 & 11.38 \\
\hline
\end{tabular}




\subsection{Independent variables}

Based on the discussion of the determinants of resilience, this section outlines the available variables included in the analysis (precise definitions are outlined in Table 3).First, the initial economic conditions are controlled for by using the 2007 employment rate, whilst the industrial structure is measured by the employment shares of different sectors associated with the crisis such as manufacturing (A, SIC 2007), total services (G-Q, SIC 2007), banking insurance and finance (K-N, SIC 2007) and construction (F, SIC 2007). Similar variables have been used in recent studies such as Lee (2014) (Table 3). Industrial diversity/specialisation is represented by using the natural logarithm of the Herfindahl-Hirschman Index (HHI) of sectoral employment (A-U, SIC 2007). The HHI is the sum of the squares for the employment shares of each economic sector in a LAD after standardisation to account for missing values mainly in agriculture (A, SIC 2007) and energy and water sections (B, D and E, SIC 2007). It shows the concentration of economic activity in different sectors where a higher value implies greater specialisation

Entrepreneurship is measured in terms of new firm births per 1000 population; this is averaged over the 2004-2007 period to avoid the year-to-year fluctuations that can occur at a local level. Three variables are used to represent human capital: the shares of degree and higher qualifications and those with no qualifications among the working age population in 2007 measure the initial stock of human capital, whilst the average employee training rate 2004-2007 reflects the culture of on-the-job training. The former two have been widely used (Di Caro 2015b; Hill et al. 2010; Lee 2014), whilst it is the first time that employee training has been used in resilience studies as a reflection of on-the-job created human capital. In terms of demographics, the population shares of three age groups (20-34, 35-49 and 50-64) are used. The natural logarithm of population density tests for the effects of urbanity, whilst a number of geographical dummies are included to examine locational effects. The models also initially included the size of the public sector as an independent variable. However, the coefficients were invariably insignificant and did not affect the significance of other variables; for simplicity, these are excluded from the reported results. One explanation for this lack of significance could be that its initial positive contribution to maintaining employment levels (ONS 2009) was counteracted by post-2009 austerity measures which saw a significant reduction of public sector jobs (Clayton 2011). Indeed, the share of the public sector in total employment at the national level reached a peak of $25 \%$ in 2010 before dropping to $23.4 \%$ in 2013, its lowest rate since data started in 2004.

Table 4 presents the descriptive statistics of the independent variables excluding the geography related dummies, whilst Table 5 depicts the relevant correlation matrix. As expected, high correlations are observed among the industrial sector variables and among the age groups.

It should be noted that a few observations are missing due to lack of data, typically due to unreliable sample sizes for some areas with extremely small populations. The City of London and Isles of Scilly are missing from all models, whilst West Somerset is missing from models 1 and 4 (these three areas have the smallest, second smallest and sixth smallest working population of all the areas covered by the initial sample). 
Table 3 Range of independent variables and definitions

\begin{tabular}{|c|c|c|c|}
\hline Theme & Variable & Definition & $\begin{array}{l}\text { Papers with similar } \\
\text { variable }\end{array}$ \\
\hline $\begin{array}{l}\text { Initial economic } \\
\text { conditions }\end{array}$ & EMP_2007 & Employment rate $16+2007$ & Lee (2014) \\
\hline \multirow[t]{4}{*}{$\begin{array}{l}\text { Sectoral composition } \\
\text { of employment }\end{array}$} & MANF & $\begin{array}{l}\text { Percentage of all in employment who } \\
\text { work in-Manufacturing (C, SIC } \\
\text { 2007) } 2007\end{array}$ & \multirow[t]{4}{*}{ Lee (2014) } \\
\hline & TS & $\begin{array}{l}\text { Percentage of all in employment who } \\
\text { work in-total services (G-Q, SIC } \\
\text { 2007) } 2007\end{array}$ & \\
\hline & $\mathrm{BIF}$ & $\begin{array}{l}\text { Percentage of all in employment who } \\
\text { work in-banking, finance and } \\
\text { insurance (K-N, SIC 2007) } 2007\end{array}$ & \\
\hline & $\mathrm{CON}$ & $\begin{array}{l}\text { Percentage of all in employment who } \\
\text { work in-Construction (F, SIC 2007) } \\
2007\end{array}$ & \\
\hline Industrial diversity & LN_HHI & $\begin{array}{l}\text { Natural Logarithm of } \\
\text { Herfindahl-Hirschman Index for } \\
\text { employment on sections }\end{array}$ & $\begin{array}{l}\text { Lee (2014), Fingleton } \\
\text { and Palombi (2013) } \\
\text { and Di Caro (2015b) }\end{array}$ \\
\hline Entrepreneurship & ENTR & $\begin{array}{l}\text { Average firm birth per } 1000 \text { population } \\
\text { 2004-2007 }\end{array}$ & $\begin{array}{l}\text { Bishop and Shilcof } \\
\text { (2016) }\end{array}$ \\
\hline \multirow[t]{3}{*}{$\begin{array}{l}\text { Employee training and } \\
\text { human capital }\end{array}$} & TRAIN & $\begin{array}{l}\text { Average \% of employee training } \\
\text { 2004-2007 }\end{array}$ & \\
\hline & DEGREE & $\begin{array}{l}\% \text { of population with degree or } \\
\text { equivalent and above } 2007\end{array}$ & \multirow[t]{5}{*}{$\begin{array}{l}\text { Hill et al. (2010), Lee } \\
\text { (2014) and Di Caro } \\
(2015 b)\end{array}$} \\
\hline & NO_QUAL & $\begin{array}{l}\% \text { of population with no qualifications } \\
2007\end{array}$ & \\
\hline \multirow[t]{3}{*}{ Demographics } & AGE_20_34 & Population aged $20-34$ as a $\%$ of total & \\
\hline & AGE_35_49 & Population aged $35-49$ as a $\%$ of total & \\
\hline & AGE_50_64 & Population aged $50-64$ as a $\%$ of total & \\
\hline Population density & LN_DENSITY & $\begin{array}{l}\text { Natural logarithm of population density } \\
2007\end{array}$ & $\begin{array}{l}\text { Capello et al. (2015), } \\
\text { Brakman et al. } \\
\text { (2014) and Lee } \\
\text { (2014) }\end{array}$ \\
\hline \multirow[t]{4}{*}{ Geography } & NOE & $\begin{array}{l}\text { North of England dummy including } \\
\text { former regions North East, North } \\
\text { West and Yorkshire and the Humber }\end{array}$ & \multirow[t]{4}{*}{ Lee (2014) } \\
\hline & MIDLANDS & $\begin{array}{l}\text { Midlands dummy including East and } \\
\text { West Midlands }\end{array}$ & \\
\hline & SCOTLAND & Scotland dummy & \\
\hline & WALES & Wales dummy & \\
\hline
\end{tabular}


Table 4 Descriptive statistics of the independent variables

\begin{tabular}{lcrrrr}
\hline Variable & Obs & Mean & \multicolumn{1}{c}{ SD } & \multicolumn{1}{c}{ Min } & Max \\
\hline EMP_2007 & 378 & 60.40 & 4.84 & 45.60 & 71.90 \\
MANF & 377 & 12.48 & 5.02 & 1.90 & 29.60 \\
TS & 379 & 75.44 & 6.20 & 56.70 & 93.80 \\
BIF & 376 & 14.27 & 6.40 & 2.80 & 72.50 \\
CON & 376 & 8.87 & 2.52 & 1.50 & 18.30 \\
LN_HHI & 378 & 7.51 & 0.10 & 7.26 & 7.88 \\
ENTR & 380 & 7.65 & 11.10 & 3.00 & 218.82 \\
TRAIN & 378 & 10.72 & 1.56 & 5.90 & 14.60 \\
DEGREE & 379 & 19.32 & 8.65 & 5.90 & 75.80 \\
NO_QUAL & 378 & 12.74 & 4.51 & 2.00 & 29.90 \\
AGE_20_34 & 380 & 18.40 & 4.98 & 10.70 & 38.20 \\
AGE_35_49 & 380 & 22.21 & 1.39 & 18.00 & 26.80 \\
AGE_50_64 & 380 & 18.75 & 2.55 & 9.00 & 23.70 \\
LN_DENSITY & 380 & 6.31 & 1.47 & 2.20 & 9.51 \\
\hline
\end{tabular}

Ryedale, Melton, Mole Valley and Forest Heath are also missing from models 3 and 6. The decision to exclude these places on a model by model basis rather than across the different specifications was made on the basis of exploiting the maximum information available. Moreover, regressions run with the same sample of LADs (i.e. excluding all these LADs in every equation) show no significant differences from the analysis presented below. The independent variables explain approximately $30 \%$ of the dependent's total variation which is reasonable considering the cross-sectional nature of the model and heterogeneity of LADs and is not uncommon in studies of this type (Wooldridge 2015).

Table 6 presents the results of the linear regression models. In devising the estimation strategy, all of the independent variables were initially considered simultaneously. However, high VIFs for the age group 50-64 and the total services' variables (13.62 and 11.93 respectively) confirmed multicollinearity concerns for these independents with other measures of age and industrial structure. This dictated the inclusion of different sets of variables in different specifications. Hence, models 1-3 omit the 50-64 age group, whilst models 4-6 include this age group but omit the 20-34 age group. Models 1 and 4 include manufacturing only, whilst models 2 and 5 include total services. In addition, to explore the potential impact of industrial structure, it was decided to include variables BIF and $\mathrm{CON}$ in a separate model (models 3 and 6) as these sectors might be expected to have been particularly vulnerable in the 2008 crisis given the origin of the crisis in the financial and housing markets. Models 3 and 6 also serve as a robustness check of the results in the other the specifications.

\section{Results}

Due to the calculation of the dependent variable, positive coefficients imply a deeper employment impact, whilst the opposite is true for negative coefficients. Following the 


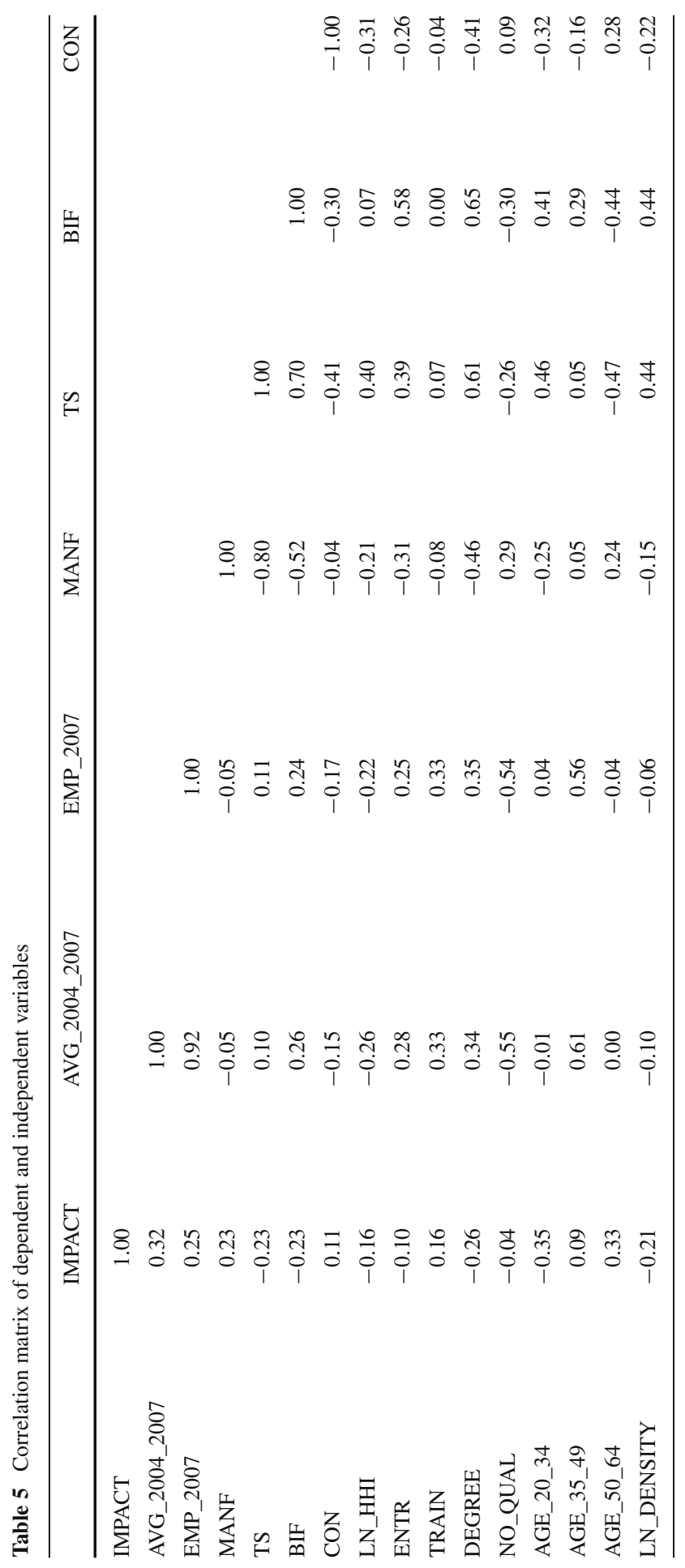




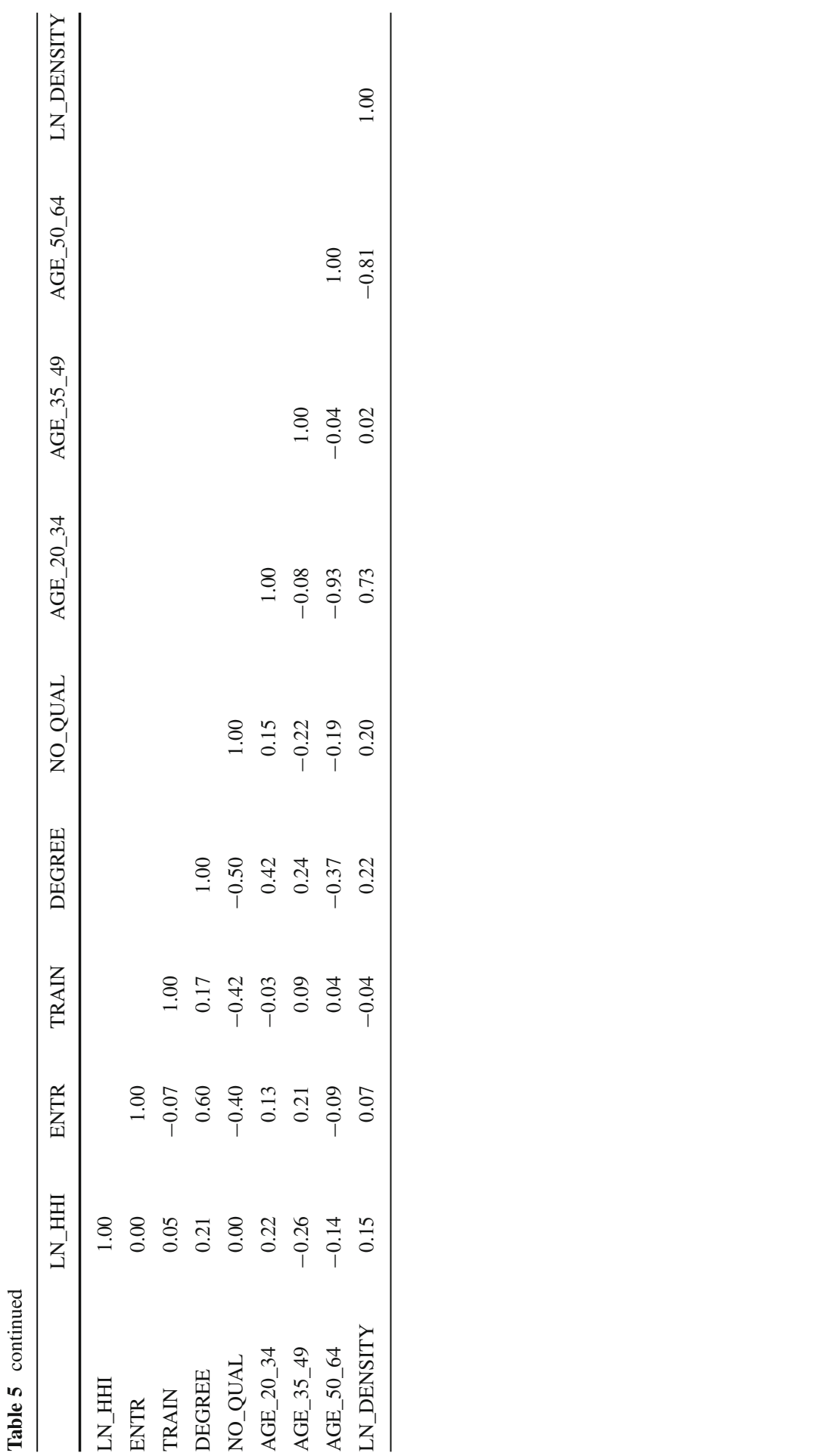


Table 6 Cross-sectional regression results for IMPACT

\begin{tabular}{|c|c|c|c|c|c|c|}
\hline & $\begin{array}{l}\text { Model } 1 \\
\text { Coef./se }\end{array}$ & $\begin{array}{l}\text { Model } 2 \\
\text { Coef./se }\end{array}$ & $\begin{array}{l}\text { Model } 3 \\
\text { Coef./se }\end{array}$ & $\begin{array}{l}\text { Model } 4 \\
\text { Coef./se }\end{array}$ & $\begin{array}{l}\text { Model } 5 \\
\text { Coef./se }\end{array}$ & $\begin{array}{l}\text { Model } 6 \\
\text { Coef./se }\end{array}$ \\
\hline EMP_2007 & $\begin{array}{l}0.247 * * * \\
(0.04)\end{array}$ & $\begin{array}{l}0.253^{* * *} \\
(0.04)\end{array}$ & $\begin{array}{l}0.249 * * * \\
(0.04)\end{array}$ & $\begin{array}{l}0.226 * * * \\
(0.03)\end{array}$ & $\begin{array}{l}0.232 * * * \\
(0.03)\end{array}$ & $\begin{array}{l}0.229 * * * \\
(0.03)\end{array}$ \\
\hline MANF & $\begin{array}{l}0.009 \\
(0.03)\end{array}$ & & & $\begin{array}{l}0.005 \\
(0.03)\end{array}$ & & \\
\hline TS & & $\begin{array}{l}0.031 \\
(0.03)\end{array}$ & & & $\begin{array}{l}0.04 \\
(0.03)\end{array}$ & \\
\hline BIF & & & $\begin{array}{l}-0.024 \\
(0.03)\end{array}$ & & & $\begin{array}{l}-0.023 \\
(0.03)\end{array}$ \\
\hline $\mathrm{CON}$ & & & $\begin{array}{l}-0.006 \\
(0.03)\end{array}$ & & & $\begin{array}{l}-0.001 \\
(0.04)\end{array}$ \\
\hline LN_HHI & $\begin{array}{l}-0.098 \\
(1.62)\end{array}$ & $\begin{array}{l}-0.747 \\
(1.84)\end{array}$ & $\begin{array}{l}-0.035 \\
(1.73)\end{array}$ & $\begin{array}{l}-0.496 \\
(1.62)\end{array}$ & $\begin{array}{l}-1.304 \\
(1.77)\end{array}$ & $\begin{array}{l}-0.406 \\
(1.77)\end{array}$ \\
\hline ENTR & $\begin{array}{l}0.112^{* *} \\
(0.04)\end{array}$ & $\begin{array}{l}0.102 * \\
(0.05)\end{array}$ & $\begin{array}{l}0.133^{* *} \\
(0.05)\end{array}$ & $\begin{array}{l}0.063 \\
(0.05)\end{array}$ & $\begin{array}{l}0.051 \\
(0.05)\end{array}$ & $\begin{array}{l}0.088 \\
(0.06)\end{array}$ \\
\hline TRAIN & $\begin{array}{l}0.192 * \\
(0.09)\end{array}$ & $\begin{array}{l}0.200^{*} \\
(0.09)\end{array}$ & $\begin{array}{l}0.196^{*} \\
(0.09)\end{array}$ & $\begin{array}{l}0.201 * \\
(0.09)\end{array}$ & $\begin{array}{l}0.211 * * \\
(0.09)\end{array}$ & $\begin{array}{l}0.207 * * \\
(0.09)\end{array}$ \\
\hline DEGREE & $\begin{array}{l}-0.056^{* *} \\
(0.02)\end{array}$ & $\begin{array}{l}-0.064 * * \\
(0.02)\end{array}$ & $\begin{array}{l}-0.055^{*} \\
(0.03)\end{array}$ & $\begin{array}{l}-0.062^{* *} \\
(0.02)\end{array}$ & $\begin{array}{l}-0.071^{* * *} \\
(0.02)\end{array}$ & $\begin{array}{l}-0.061 * * \\
(0.02)\end{array}$ \\
\hline NO_QUAL & $\begin{array}{l}0.079 \\
(0.05)\end{array}$ & $\begin{array}{l}0.086^{*} \\
(0.05)\end{array}$ & $\begin{array}{l}0.091 * \\
(0.05)\end{array}$ & $\begin{array}{l}0.081 * \\
(0.04)\end{array}$ & $\begin{array}{l}0.090^{* *} \\
(0.04)\end{array}$ & $\begin{array}{l}0.094 * * \\
(0.04)\end{array}$ \\
\hline AGE_20_34 & $\begin{array}{l}-0.222^{* * *} \\
(0.03)\end{array}$ & $\begin{array}{l}-0.222 * * * \\
(0.03)\end{array}$ & $\begin{array}{l}-0.214 * * * \\
(0.04)\end{array}$ & & & \\
\hline AGE_35_49 & $\begin{array}{l}-0.338^{* * *} \\
(0.1)\end{array}$ & $\begin{array}{l}-0.333 * * * \\
(0.09)\end{array}$ & $\begin{array}{l}-0.312^{* *} \\
(0.11)\end{array}$ & $\begin{array}{l}-0.176^{*} \\
(0.09)\end{array}$ & $\begin{array}{l}-0.173^{*} \\
(0.09)\end{array}$ & $\begin{array}{l}-0.157 \\
(0.11)\end{array}$ \\
\hline AGE_50_64 & & & & $\begin{array}{l}0.443^{* * * *} \\
(0.08)\end{array}$ & $\begin{array}{l}0.447 * * * \\
(0.09)\end{array}$ & $\begin{array}{l}0.423 * * * \\
(0.09)\end{array}$ \\
\hline LN_DENSITY & $\begin{array}{l}0.341 * * * \\
(0.09)\end{array}$ & $\begin{array}{l}0.302^{* * *} \\
(0.1)\end{array}$ & $\begin{array}{l}0.330 * * * \\
(0.09)\end{array}$ & $\begin{array}{l}0.386^{* * * *} \\
(0.1)\end{array}$ & $\begin{array}{l}0.343^{* *} \\
(0.12)\end{array}$ & $\begin{array}{l}0.370^{* *} \\
(0.12)\end{array}$ \\
\hline NOE & $\begin{array}{l}0.704^{* * * *} \\
(0.22)\end{array}$ & $\begin{array}{l}0.844 * * * \\
(0.2)\end{array}$ & $\begin{array}{l}0.658 * * \\
(0.26)\end{array}$ & $\begin{array}{l}0.462 * \\
(0.25)\end{array}$ & $\begin{array}{l}0.622 * * \\
(0.21)\end{array}$ & $\begin{array}{l}0.429 \\
(0.28)\end{array}$ \\
\hline MIDLANDS & $\begin{array}{l}0.863^{* * * *} \\
(0.24)\end{array}$ & $\begin{array}{l}1.068^{* * * *} \\
(0.21)\end{array}$ & $\begin{array}{l}0.793 * * \\
(0.29)\end{array}$ & $\begin{array}{l}0.596^{*} \\
(0.29)\end{array}$ & $\begin{array}{l}0.826^{* * * *} \\
(0.23)\end{array}$ & $\begin{array}{l}0.532 \\
(0.32)\end{array}$ \\
\hline SCOTLAND & $\begin{array}{l}0.956^{* * * *} \\
(0.3)\end{array}$ & $\begin{array}{l}0.961 * * \\
(0.31)\end{array}$ & $\begin{array}{l}0.858 * * \\
(0.34)\end{array}$ & $\begin{array}{l}0.435 \\
(0.33)\end{array}$ & $\begin{array}{l}0.457 \\
(0.34)\end{array}$ & $\begin{array}{l}0.37 \\
(0.39)\end{array}$ \\
\hline WALES & $\begin{array}{l}0.074 \\
(0.35)\end{array}$ & $\begin{array}{l}0.219 \\
(0.33)\end{array}$ & $\begin{array}{l}-0.038 \\
(0.4)\end{array}$ & $\begin{array}{l}-0.197 \\
(0.38)\end{array}$ & $\begin{array}{l}-0.025 \\
(0.36)\end{array}$ & $\begin{array}{l}-0.291 \\
(0.42)\end{array}$ \\
\hline
\end{tabular}


Table 6 continued

\begin{tabular}{lllllll}
\hline & $\begin{array}{l}\text { Model 1 } \\
\text { Coef./se }\end{array}$ & $\begin{array}{l}\text { Model 2 } \\
\text { Coef./se }\end{array}$ & $\begin{array}{l}\text { Model 3 } \\
\text { Coef./se }\end{array}$ & $\begin{array}{l}\text { Model 4 } \\
\text { Coef./se }\end{array}$ & $\begin{array}{l}\text { Model 5 } \\
\text { Coef./se }\end{array}$ & $\begin{array}{l}\text { Model 6 } \\
\text { Coef./se }\end{array}$ \\
\hline Constant & -4.89 & -2.509 & -5.972 & -16.333 & -13.542 & -17.149 \\
& $(13.63)$ & $(14.16)$ & $(15.29)$ & $(13.3)$ & $(13.66)$ & $(15.51)$ \\
$R$-squared & 0.305 & 0.311 & 0.307 & 0.3 & 0.307 & 0.302 \\
N. of cases & 377 & 378 & 374 & 377 & 378 & 374 \\
\hline
\end{tabular}

$* p<0.10, * * p<0.05, * * * p<0.01$

analysis of Lee (2014), regionally clustered robust standard errors are used. A number of variables such as human capital and demographics could potentially be affected by reverse causality. However, the use of explanatory variables at the base year (2007) to examine their effect on the post-2008 crisis impact alleviate this concern in this cross-sectional analysis.

The results highlight a number of interesting points. First, initial economic conditions are consistently significant with a positive sign, suggesting that LADs with greater employment rates prior to the crisis exhibited the greatest losses of employment in the subsequent period. One possible explanation is that higher initial employment rates are an indicator of areas with tight labour markets where the profitability of the marginal worker was low and a drop in demand led to significant labour market adjustment. This result is in accordance with Lee's (2014) findings where places with higher unemployment rates had a smaller crisis impact than places with lower ones. Second, all of the sectoral variables, including the specialisation index failed to provide statistically significant results, providing no evidence that particular sectors were the source of greater vulnerability for the LADs. This is in contrast to Lee's (2014) study which finds statistically significant and negative effects for employment in manufacturing, financial services and construction sectors.

The results on specialisation confirm the lack of significance found in sectoral results. Di Caro (2015b), Fingleton and Palombi's (2013) and Brakman et al's (2014) studies on the other hand find that diversity has a positive effect (or specialisation has a negative one) on resilience. The differences between this paper and others could be attributed to a range of factors such as the different geographies examined, the different datasets used and temporal differences, since each study examines a different time period. If not attributed to data considerations, the lack of statistical significance on the sectoral and diversification variables could indicate that post-2010 crisis has spread across all sectors.

Entrepreneurship exhibits statistically significant and positive coefficients in models 1-3 and statistically insignificant coefficients in models 4-6. The loss of statistical significance across models indicates considerable sensitivity across specifications. This diminishes the robustness of the results and does not allow for the confirmation of a significant effect for entrepreneurship suggested by other studies (Bishop and Shilcof 2016; Williams and Vorley 2014; Williams et al. 2013). The opposing effects of firm formation on employment generation-dynamism and flexibility on the one hand and the fact that most new firms tend to be small enterprises with relatively 
limited access to credit and high death rates, could potentially explain the sensitivity of the results to small changes in specification. In addition, it could be the case that entrepreneurship is important to the restructuring or recovery phase rather than the crisis impact (Bishop and Shilcof 2016; Williams and Vorley 2014; Williams et al. 2013).

As far as the human capital variables are concerned, the training variable is consistently significant and positive. This outcome could be viewed in terms of a potential self-selection bias, since companies that engage in employee training tend to be larger in size (Kotey and Folker 2007) and potentially less flexible at times of adversity. The result suggests that employee training may be signalling firms with lagging productivity (Bartel 1994), under restructuring, highly unionised and/or with low stocks of skills (Almeida-Santos and Mumford 2005; Molina and Ortega 2003). If this is the case, then these firms may be more vulnerable in times of economic stress. The share of degree holders is consistently negative and statistically significant across all models, suggesting that places with a higher share of degree holders have suffered a smaller crisis impact. Conversely, the coefficients for the share of population with no qualifications are statistically significant in models $2-6$ and have a positive sign, deepening the impact of the crisis for LADs. This is in agreement to Lee's (2014) results and suggests that places with higher levels human capital were better able to mitigate the recession effects due to the attributes associated with transferable knowledge and skills.

The demographic structure of a LAD also emerges as a significant factor. Models 13 include the age groups 20-34 and 35-49. Both variables have consistently significant and negative coefficients implying that the higher the population share of these age groups, the greater the mitigation of the employment impact. An F-test for the equality of the coefficients fails to confirm that one of the groups has a greater contribution than the other. Models 3-6 consider the age groups 35-49 and 50-64. The coefficient for the 35-49 group is mostly significant and negative at the $10 \%$ level, whilst the coefficients for the 50-64 group are significant and positive, indicating a detrimental effect of high shares of this group. It is possible that age exhibits an inverted Ushaped relationship to the crisis impact, in agreement with studies of the effects of demographics on various human capital, productivity and growth measures (Brunow and Hirte 2009a, b; Poot 2008; Skirbekk 2004). This also suggests that the combination of a more youthful population but with significant work experience is the most helpful demographic attribute.

Since the variables included refer to the year 2007, it is unlikely that extraordinary migration movements due to the economic crisis have affected the results of the demographic variables. However, migration figures for 2007 (as well as its components of international and domestic migration) are positively correlated with the 20-34 age group, have no relationship to the 35-49 group and exhibit a negative relationship to the 50-64 group. This could be a sign that age is proxying or is affected by previous migration, and hence, it is worth further investigation. Replacing the age groups with inward migration for 2007 provides statistically significant results for the latter but only at the $10 \%$ level, leading to a poorer fit of the model than with the age variables. In addition, separating migration into domestic and international does not provide any statistically significant results. As a result, it can be argued that the use of demographic groups is a better proxy even if it partly reflects migration. 
Population density has consistently significant and positive coefficients, suggesting a greater crisis impact in more densely populated areas. This result could be linked to the social characteristics of highly populated areas. Capello et al. (2015) argue that it is the qualitative characteristics-infrastructure, quality of production and factors etc. - of cities that matter to resilience rather than size and agglomeration as well as the lower impact found in "sheltered" economies (Fratesi and Rodríguez-Pose 2016). In terms of the recession's geographical footprint, there is evidence of the impact being more severe than the rest of GB for LADs in the North of England and Midlands agreeing in part with Lee's (2014) results for the North. The two dummies have statistically significant and positive coefficients in models 1-5, and the same holds for the Scotland dummy in models 1-3. Considering the magnitude of the impact, the statistical significance of the coefficients for NOE, MIDLANDS confirms that LADs in these regions had deeper crisis impact than the rest of GB, whilst for SCOTLAND, the results are inconclusive.

\section{Conclusions}

The concept of resilience provides a useful framework with which to examine the recent economic crisis as it facilitates a focus on the factors behind both the differential impact and success of the recovery stage across spatial areas. The theoretical and empirical investigation of resilience is still being developed, and this special issue is a significant step in the development of appropriate measures and understanding of the factors affecting resilience. This paper makes a contribution by taking an averaging approach to measuring pre- and post-recession employment conditions to avoid issues associated with year-to-year volatility at a local level. A number of factors affecting the crisis impact are identified and tested. These factors stem from existing research on resilience as well as economic theory on growth and employment and include the initial economic conditions, sectoral specialisation, industrial diversification, human capital, entrepreneurship, demographics, urbanisation and geographical variables.

The analysis supports the view that the recession had variable effects across GB due to a number of factors. The impact was deeper in places with higher employment rates in 2007 but also in LADs of the traditionally lagging North and Midlands. A mixture of dynamism, skills and experience at the individual level appears to have the most beneficial effect for LADs with the share of degree holders, and the age groups 20-34 and 35-49 mitigating the crisis impact whilst employee training, perhaps as an indicator of underlying problems, and the group 50-64 having the opposite effect. The lack of consistently significant results for industrial structure, diversity and entrepreneurship may suggests that, in the medium term, the systemic nature of the crisis had spread to all sectors of the economy and worsened the environment for new firms counterbalancing any potential benefits of firm formation.

The approach adopted in this study has a number of limitations. In particular, the low spatial scale of the study inevitably limits the range of variables that can be included in the analysis, and some potentially important variables may have been omitted. In addition, the cross-sectional method utilised limits the causal inferences that can be made from the study. Nevertheless, the approach has a number of advantages that might 
usefully inform future studies in the area. In particular, whilst using local level data has major advantages in terms of increasing sample sizes and assessing the variability of impacts across space, the use of single-year observations based on sample data with wide confidence intervals may yield unreliable conclusions. The approach to averaging data at this spatial scale has the potential to avoid this issue and improve the reliability of results. In addition, the study opens numerous strands for further research. Employment rates are only one of a range of variables worth exploring, and it would be interesting to repeat the methodology of this study using other measures such as unemployment rates and household disposable income. Further research might also more closely examine the differences between urban and rural areas and augment the list of independent variables in order to identify resilience building factors.

Finally, in terms of policy implications, perhaps the most interesting aspect of the study is the importance of high level qualifications and a relatively youthful population in mitigating the crisis impact. Whilst it is difficult for policy makers to directly control demographics, investment in higher education institutions that both supply qualifications and attract young people who may stay and live in the area in which they study is a potential development strategy. Those areas that are weak in the provision of higher education might seek to persuade national decision-makers to assist in capacity building or develop strategies that seek to attract recently qualified graduates to jobs within the subregion. This might include both domestic migrants and overseas migrants who are seeking to develop a career in their country of study. Policy makers might also consider investment in those amenities and cultural aspects of a local environment that might prove attractive to young, educated individuals.

Open Access This article is distributed under the terms of the Creative Commons Attribution 4.0 International License (http://creativecommons.org/licenses/by/4.0/), which permits unrestricted use, distribution, and reproduction in any medium, provided you give appropriate credit to the original author(s) and the source, provide a link to the Creative Commons license, and indicate if changes were made.

\section{References}

Acs Z, Mueller P (2008) Employment effects of business dynamics: mice, gazelles and elephants. Small Bus Econ 30:85-100. doi:10.1007/s11187-007-9052-3

Almeida-Santos F, Mumford K (2005) Employee training and wage compression in Britain. Manch Sch 73:321-342. doi:10.1111/j.1467-9957.2005.00449.x

Audretsch DB, Belitski M, Desai S (2015) Entrepreneurship and economic development in cities. Ann Reg Sci 55:33-60. doi:10.1007/s00168-015-0685-x

Bartel AP (1994) Productivity gains from the implementation of employee training programs. Indus Relat J Econ Soc 33:411-425. doi:10.1111/j.1468-232X.1994.tb00349.X

Becker GS (1962) Investment in human capital: a theoretical analysis. J Pol Econ 70:9-49. doi:10.2307/ 1829103

Bishop P (2012) Knowledge, diversity and entrepreneurship: a spatial analysis of new firm formation in Great Britain. Entrep Reg Dev 24:641-660. doi:10.1080/08985626.2011.617786

Bishop P, Shilcof D (2016) The spatial dynamics of new firm births during an economic crisis: the case of Great Britain, 2004-12 Working paper. Entrep Reg Dev (forthcoming)

Brakman S, Garretsen H, van Marrewijk C (2014) The crisis and regional resilience in Europe: on the importance of urbanization and specialization. CESifo Group Munich. Working Paper

Bristow G, Healy A (2013) Regional resilience: an agency perspective. Reg Stud 48:923-935. doi:10.1080/ 00343404.2013 .854879 
Brunow S, Hirte G (2009a) Regional age structure and economic growth: an econometric study for German regions, Dresden discussion paper series in economics No. 04/09

Brunow S, Hirte G (2009b) The age pattern of human capital and regional productivity: a spatial econometric study on german regions. Pap Reg Sci 88:799-823. doi:10.1111/j.1435-5957.2009.00228.x

Capello R, Caragliu A, Fratesi U (2015) Spatial heterogeneity in the costs of the economic crisis in Europe: Are cities sources of regional resilience? J Econ Geogr. doi:10.1093/jeg/lbu053

Capello R, Caragliu A, Fratesi U (2016) The costs of the economic crisis: Which scenario for the European regions? Environ Plan C Gov Policy 34:113-130. doi:10.1177/0263774x15614471

Cellini R, Di Caro P, Torrisi G (2014) Regional resilience in Italy: Do employment and income tell the same story?. University Library of Munich, Germany

Cellini R, Torrisi G (2014) Regional resilience in Italy: a very long-run analysis. Reg Stud. doi:10.1080/ 00343404.2013 .861058

Clayton N (2011) The spatial impacts of the recession. In: Bailey D, Chapain C (eds) The recession and beyond: local and regional responses to the downturn. Routledge, New York

Di Caro P (2015a) Recessions, recoveries and regional resilience: evidence on Italy. Camb J Reg Econ Soc 8:273-291. doi:10.1093/cjres/rsu029

Di Caro P (2015b) Testing and explaining economic resilience with an application to Italian regions. Pap Reg Sci. doi:10.1111/pirs. 12168

Fingleton B, Garretsen H, Martin R (2012) Recessionary shocks and regional employment: evidence on the resilience of U.K regions. J Reg Sci 52:109-133. doi:10.1111/j.1467-9787.2011.00755.x

Fingleton B, Palombi S (2013) Spatial panel data estimation, counterfactual predictions, and local economic resilience among British towns in the Victorian era. Reg Sci Urban Econ 43:649-660. doi:10.1016/j. regsciurbeco.2013.04.005

Fotopoulos G (2014) On the spatial stickiness of UK new firm formation rates. J Econ Geogr 14:651-679. doi:10.1093/jeg/lbt011

Fratesi U, Rodríguez-Pose A (2016) The crisis and regional employment in Europe: What role for sheltered economies? Camb J Reg Econ Soc. doi:10.1093/cjres/rsv032

Gripaios P, Bishop P (2006) Objective one funding in the UK: a critical assessment. Reg Stud 40:937-951. doi:10.1080/00343400600877839

Hashimoto M (1981) Firm-specific human capital as a shared investment. Am Econ Rev 71:475-482

Hill E, Clair T, Wial H, Wolman H, Atkins P, Blumenthal P, Ficenec S, Fiedhoff A (2010) Economic shocks and regional economic resilience. In: Paper to conference on urban and regional policy and its effects: building resilient regions, Washington DC 2010, pp 20-21

Holling C (1996) Engineering resilience versus ecological resilience. In: Schulze PC (ed) Engineering within ecological constraints. National Academies Press, Washington, DC, pp 31-43

Kotey B, Folker C (2007) Employee training in SMEs: effect of size and firm type-family and nonfamily. J Small Bus Manag 45:214-238. doi:10.1111/j.1540-627X.2007.00210.x

Lee N (2014) Grim down South? The determinants of unemployment increases in British cities in the 2008-2009 recession. Reg Stud 48:1761-1778. doi:10.1080/00343404.2012.709609

Martin R (2012) Regional economic resilience, hysteresis and recessionary shocks. J Econ Geogr 12:1-32. doi: $10.1093 / \mathrm{jeg} / \mathrm{lbr} 019$

Martin R, Sunley P (2014) On the notion of regional economic resilience: conceptualization and explanation. J Econ Geogr. doi:10.1093/jeg/lbu015

Molina JA, Ortega R (2003) Effects of employee training on the performance of North-American firms. Appl Econ Lett 10:549-552. doi:10.1080/1350485032000100297

ONS (2009) The impact of the recession on the labour market. HMSO, London

Poot J (2008) Demographic change and regional competitiveness: the effects of immigration and ageing. Int J For Innov Policy 4:129-145

Robertson A, Tracy CS (1998) Health and productivity of older workers. Scand J Work Environ Health 24:85-97. doi:10.2307/40966742

Simmie J, Martin R (2010) The economic resilience of regions: towards an evolutionary approach. Camb J Reg Econ Soc 3:27-43. doi:10.1093/cjres/rsp029

Skirbekk V (2004) Age and individual productivity: a literature survey. Vienna Yearb Popul Res 2:133-153

Soininen J, Puumalainen K, Sjögrén H, Syrjä P (2012) The impact of global economic crisis on SMEs: Does entrepreneurial orientation matter? Manag Res Rev 35:927-944. doi:10.1108/01409171211272660

Treado CD, Giarratani F (2008) Intermediate steel-industry suppliers in the Pittsburgh region: a cluster-based analysis of regional economic resilience. Econ Dev Quart 22:63-75. doi:10.1177/0891242407311268 
Walker B, Holling CS, Carpenter SR, Kinzig A (2004) Resilience, adaptability and transformability in social-ecological systems. Ecol Soc 9:5

Williams N, Vorley T, Ketikidis PH (2013) Economic resilience and entrepreneurship: a case study of the Thessaloniki city region. Local Econ 28:399-415. doi:10.1177/0269094213475993

Williams N, Vorley T (2014) Economic resilience and entrepreneurship: lessons from the Sheffield city region. Entrepr Reg Dev. doi:10.1080/08985626.2014.894129 